\title{
A BRIEF OVERVIEW OF THE CIVIL UNION ACT
}

\section{ISSN 1727-3781}

2010 VOLUME 13 No 1 


\section{A BRIEF OVERVIEW OF THE CIVIL UNION ACT*}

\section{N Ntlama ${ }^{* *}$}

\section{Introduction}

Following the adoption of the Civil Union Act 17 of 2006 (Civil Union Act) on 1 December 2006, South Africa became one of very few countries to confer legal protection and marriage benefits on partners in same-sex relationships. The legislation was adopted as a direct response to the landmark decision of the Constitutional Court in Minister of Home Affairs $v$ Fourie. ${ }^{1}$ The Court had declared the lack of the legal recognition of same-sex relationships unconstitutional and had given Parliament a period of one year in which to develop a remedy that would allow same-sex partners to formalise their relationships. The Court had also cautioned Parliament to be sensitive and not to provide a remedy that would be calculated and perceived as producing new forms of marginalisation. ${ }^{2}$

In this regard, Parliament opted to develop a separate institution of marriage, apart from the existing forms of marriage such as civil or customary marriages. ${ }^{3}$ This new institution of marriage has generated extensive and complex questions in relation to the quality of legal protection accorded to partners in same-sex relationships. These questions touch on very broad issues such as institutional, social and religious beliefs, views and opinions, civil rights, ethics,

* $\quad 17$ of 2006.

** Nomthandazo Ntlama. B.Juris, LLB, LLM, Certificate in Comparative Human Rights. Senior Lecturer: Department of Public, Constitutional, and International Law, University of South Africa.

12006 (1) SA 542 (CC) (hereafter Fourie).

2 See Fourie par 139 and 150.

3 It is worth noting that South Africa has not as yet recognised either Islamic or Hindu marriages. See also Amod v Multilateral Motor Vehicle Accident Fund 199712 BCLR $1726(\mathrm{CC})$. 
values and principles. ${ }^{4}$ They undermine the development of a single strategy that will draw an appropriate balance between certain competing rights such as the rights to freedom of sexual orientation and freedom of religion. Such a balance may, however, be necessary to ensure that the substantive translation of the right to equality is an actuality for couples in same-sex relationships.

The purpose of this contribution is to provide a succinct overview and analysis of the features of the Act. The objective is to determine the significance of the Act for the substantive translation of the right to freedom of sexual orientation vis-à-vis the right to freedom of religion within the framework of the right to equality.

It is argued, firstly, that the Act has the potential to produce new forms of marginalisation, despite the caution by the Court. Secondly, the categorisation of marriages into heterosexual and homosexual marriages or civil unions has created legal uncertainty about the essence of the notion of equal rights for all, without distinction, as envisaged in the Constitution. Lastly, the allocation of people into various categories rather than allowing them to be just 'human beings' could defeat the purpose of establishing a 'just' society based on democratic values, social justice and fundamental human rights.

The intention is not to argue for a 'one-size-fits-all' approach, but to identify some of the factors which may be a barrier to the implementation of the Act and which could undermine the equal worth of persons in same-sex relationships. This contribution is therefore limited to an examination of the quality of the protection accorded to same-sex couples, and does not include an analysis of the nature of the institution of marriage itself or the theological and social dimensions of same-sex marriages. ${ }^{5}$

4 See Robinson and Swanepoel 2004 PER 87-135. They had already identified the challenges relating to same-sex relationships even before the adoption of the Act.

5 Sachs $\mathrm{J}$ in Fourie acknowledged the role played by religion in public life and strongly held that it would be out of order (the author's emphasis) to employ the religious sentiments of some as a guide to trample on the constitutional rights of others, par 92. 


\title{
2 The general features of the Act
}

The Constitutional Court has emphasised that the legislature is better placed to find the best ways of ensuring that people do not live in a state of 'legal blankness'. 6 The Court's emphasis on the role of the legislature is deeply entrenched in the various sections of the Bill of Rights of the South African Constitution. The legislature has to adopt special legal measures (such as the design and adoption of statute law) in ensuring the facilitation of fundamental change as far as the elimination of inequalities and discrimination lingering from the past are concerned. The impact of the historic past on the promotion of human rights is clearly expressed by Mahomed DP in Azapo $v$ President of the Republic of South Africa, ${ }^{7}$ where he stresses that:

\begin{abstract}
fundamental human rights became a major casualty of the conflict between the minority which reserved for itself all control over the political instruments of the state and the majority who sought to resist the domination and where their resistance was met by the laws that were designed to counter the effectiveness of such resistance. ${ }^{8}$
\end{abstract}

The requirement for the development of legal measures in the quest for the elimination of inequalities and discrimination is also endorsed in the preamble of the Promotion of Equality and the Prevention of Unfair Discrimination Act ${ }^{9}$ which provides that:

the prohibition of unfair discrimination and the promotion of the achievement of equality requires the development of special legal and other measures, of historically disadvantaged individuals, communities and social groups who were dispossessed of their land and resources, deprived of their human dignity and who continue to endure such consequences.

The adoption of the measures referred to here the engagement of a proactive and activist legislature in order to achieve the objectives envisaged in the

\footnotetext{
See Fourie par 72.

19968 BCLR 1015 (CC).

See Azapo par 1.

4 of 2000 (the Equality Act).
} 
Equality Act and the Constitution. The Constitutional Court in Carmichele $v$ Minister of Safety and Security ${ }^{10}$ supports this view:

there is a duty imposed on the state and all of its organs not to perform any act that infringes these rights. In some circumstances there would also be a positive component which obliges the state and its organs to provide appropriate protection to everyone through laws and structures designed to afford such protection. ${ }^{11}$

The adoption of the Civil Union Act therefore took place within the context and against the background of affirming the legitimacy of the development of measures that are designed to protect persons or categories of persons previously disadvantaged by unfair discrimination. ${ }^{12}$ It takes into account South Africa's history, and the prejudicial context that people in same-sex relationships find themselves in - even in the new constitutional dispensation. ${ }^{13}$ Effectively, it gives due recognition to the fact that the elimination of systematic discrimination against people in same-sex relationships cannot be achieved without positive action being taken by the state. ${ }^{14}$

This Act was adopted in the context of a specific rights perspective, in order to protect the rights of people in same-sex relationships, ${ }^{15}$ who are often and are most vulnerable to discrimination and persecution. The normative impetus and the specific focus behind the adoption of the Act is to be found in section 9 of the Constitution. ${ }^{16}$ This provision provides a sound framework for the

2001 (10) BCLR 995 (CC).

See Carmichele par 44.

See also s 14(1) of the Equality Act.

See the preamble of the Civil Union Act.

See also Ngcobo $\mathrm{J}$ in Bato Star Fishing (Pty) Ltd $v$ Minister of Environmental Affairs and Tourism 20047 BCLR 687 (CC) par 74.

See the preamble of the Civil Union Act.

S 9 provides that: "Everyone is equal before the law and has the right to equal protection and benefit of the law. Equality includes the full and equal enjoyment of all rights and freedoms. To promote the achievement of equality, legislative and other measures designed to protect or advance persons or categories of persons, disadvantaged by unfair discrimination may be taken. The state may not unfairly discriminate directly or indirectly against anyone on one or more grounds, including race, gender, sex, pregnancy, marital status, ethnic or social origin, colour, sexual orientation, age, disability, religion, conscience, belief, culture and birth. No person may unfairly discriminate directly or indirectly against anyone on one or more grounds in terms of subsection (3)." It is also provided that discrimination on one or more of the 
substantive translation and equal enjoyment of all fundamental rights in the Bill of Rights. It puts an emphasis on the centrality of the principles of equality and non-discrimination. These principles serve as the core foundation for the development of the national agenda for the promotion of equal rights for all people, including couples in same-sex relationships.

In addition, the entrenchment of equality as a foundational value in the Constitution ${ }^{17}$ plays a significant role as far as the interpretation and limitation of fundamental rights is concerned. Jagwanth argues that it may be used by the courts even where the right is not directly invoked, allowing the substantive principle of equality to be the lens through which the application of the law should take place. ${ }^{18}$ The centrality of equality as a foundational value was endorsed by the Court in Minister of Finance $v$ Van Heerden, ${ }^{19}$ where it held that:

the achievement of equality is not only a guaranteed and justiciable right in our Bill of Rights but also a core and foundational value; a standard which must inform all law and against which all law must be tested for constitutional consonance. ${ }^{20}$

The value-based approach to the right to equality in the context of the Civil Union Act is viewed as a progressive and transformative tool that seeks not only to remedy the injustices and ills of the past ${ }^{21}$ but also to ensure the development of affirmative measures in order to pave the way for the future achievement of equality for same-sex couples. The emphasis on the promotion of foundational values complements the purpose of the new constitutional and democratic order. The purpose of such an emphasis is to affirm the need for the establishment of a society in which all human beings, including same-sex

grounds listed in subsection (3) is unfair unless it is established that the discrimination is fair.

17 See s 1, which provides that the Republic of South Africa is one sovereign, democratic state founded on the values of human dignity, the achievement of equality, the advancement of human rights and freedoms, non-racialism and non-sexism. Jagwanth "Expanding Equality" 131.

200411 BCLT 1125 (CC).

200411 BCLT 1125 (CC) par 22.

Bonthuys 2008 Sexualities 726-739. 
couples, are accorded equal dignity and respect, regardless of their membership of particular groups. ${ }^{22}$

The intersection of the right to equality and the right to human dignity $^{23}$ as envisaged in the preamble of the Act is of the utmost importance. The centrality of these rights, both in the Constitution and the Act bears witness to the lessons drawn from the past, that make these rights the cornerstone and foundational values in reconstructing the future of couples in same-sex relationships. The interdependence of these rights was similarly expressed by Sachs $\mathrm{J}$ in National Coalition for Gay and Lesbian Equality v Minister of Justice ${ }^{24}$ as follows:

the equality principle and the dignity principle should not be seen as competitive but rather as complementary. Inequality is established not simply through group-based differential treatment, but through differentiation which perpetuates disadvantage and leads to the scarring of the sense of dignity and self-worth associated with membership of the group. Conversely, an invasion of dignity is more easily established when there is an inequality of power and status between the violator and the victim. ${ }^{25}$

In essence, the interdependence of these rights (the right to equality and the right to human dignity) provides a firm basis for a deeper understanding of the function of the law, including the Civil Union Act itself, in promoting the equal worth of all human beings. It enables the development of insight into the determination of the significance of the law in addressing both the underlying social and legal networks that limit the potential of the law to generate social change. It forms the basis upon which to establish a set of demands based on the intrinsic worth of the individual. It asserts that the right to marry without regard to the sex of the parties is a fundamental right of all persons and that limiting the applicability of such a right to heterosexuals only is irrational and invidiously discriminatory. ${ }^{26}$ The extension of the right of equal opportunity to marriage for same-sex couples requires a positive action that directly benefits right to have their dignity respected and protected'.

2419981 BCLR 1517 (CC).

2519981 BCLR 1517 (CC) par 125.

26 See Wintemute Legal Recognition 1. 
such couples. Such action is necessary to contribute to the fulfilment of the government's commitment to eliminate all forms of discrimination and prejudice as required by section $7(2)^{27}$ of the Bill of Rights.

Overall, the Civil Union Act serves as a direct and accessible legal instrument in laying the foundation for the equal rights of people in same-sex relationships. It seeks to limit any potential for reliance on the courts for enforcing the right to equality because, as Mokgoro says, 'litigation tends to be the privilege of the economically empowered'. ${ }^{28}$

\section{The negative features of the Act}

After discussing the general features of the Civil Union Act, it would be reasonable to harbour a suspicion that the Act does not pass the litmus test of equitability. ${ }^{29}$ Although it appears to have asserted the right to equality by extending equal access to 'marriage' to same-sex couples, the Act seems flawed in some respects. The creation of a separate institution of 'marriage' has reduced the equal rights of couples in same-sex relationships to what Laycock et al refer to as a 'back-door' effort to undermine the general right to equality. ${ }^{30}$ The basis of this contention is the 'legal separateness' affirmed in the Civil Union Act, which categorises people in South Africa into various groupings, confining them to particular 'closets'. The categorisation may hence relegate some people to the position of second-class citizens. It further gives the impression that certain members of our society are not worthy of the equal protection envisaged in the Constitution. The view was similarly expressed by Sachs $\mathrm{J}$ in Moseneke $v$ The Master: ${ }^{31}$

it is an affront to all of us that people are still treated as [heterosexuals and homosexuals] rather than as ordinary persons seeking to [enforce their in the Bill of Rights'.

28 Mokgoro 2003 Albany Law Review 1.

29 A term extracted from the former President Mbeki, 'ANC Today', 8 Aug 2002, about his quest for the promotion of equality in South Africa.

30 See the review by Gill of Laycock, Picarello and Wilson (eds) Same-sex Marriage.

3120012 BCLR 103 (CC). 
rights] and it is in conflict with the establishment of a [just society] where rights and duties are no longer determined by [sexual orientation]. ${ }^{32}$

The legal separateness of the Act is informed by the fact that the Act firstly discriminatorily classifies the legal relationship of same-sex couples as 'unions', reducing them to nothing more than what the author would refer to as 'so-called marriages'. The classification of the relationships as 'unions' rather than actual 'marriages' effectively worsens the continued intense suffering experienced by people in same-sex relationships. The right to a 'marriage' is not equal to the right to a 'union' as the Act itself seeks to deal with solemnisation of civil unions and the consequences of a 'civil union' which is not a 'marriage'. ${ }^{33}$ In this regard, the Civil Union Act has not, for example, defined what a marriage is ${ }^{34} \mathrm{It}$ only entitles the parties to a 'union' by way of a 'marriage' or 'civil partnership'. ${ }^{35}$ The lack of definition of the word 'marriage' in the Act creates uncertainty about the establishment of legal rules relating to the enforcement of equal rights within the context of couples in same-sex relationships vis-à-vis those in heterosexual relationships.

Effectively, despite the invalidation of the common law definition of 'marriage' and section 30(1) of the Marriage $A c t^{36}$ in Fourie, the Civil Union Act does not affect the definition of the word 'marriage'. It still reserves the use of the term 'marriage' exclusively to marriage 'between a man and a woman to the exclusion of others', as is envisaged in the Marriage Act. It is uncertain whether the concept of 'marriage' is a distinct concept that remains unquestioned in law, despite its invalidation by the Court. This leaves open the question of whether or not the decision to adopt the Act was an attempt to avoid public opposition to same-sex marriages, especially by religious institutions. ${ }^{37}$ the majority at par 164 .

37 See Reddy 'The same-sex marriage complex in South Africa: some conceptual, gendered and rights-based interpretations'. 
It is noticeable that the Act denies same-sex couples the status of 'marriage' enjoyed by heterosexual couples. It could therefore violate the principles of non-discrimination on the basis of sexual orientation. The Act develops a distinct set of constitutional principles in relation to the promotion of the right to equality for persons in same-sex relationships vis-à-vis people in heterosexual relationships. It does not provide for the requirements of a valid marriage and especially within the traditional value system in terms of customary law which requires negotiations and the payment of ilobola and other related requirements before the marriage can be solemnised. It also undermines section 2(3) of the Recognition of Customary Marriages Act, ${ }^{38}$ which recognises the validity of polygamous marriages concluded in terms of the customary law system (despite the concerns the author may have about these marriages). It furthers the injury to homosexual couples and compromises the laying of the foundation for the construction of new paradigms, which need to be affirmed. ${ }^{39}$

In addition, the legal categorisation of human relationships and human beings leaves a void in the determination of the context in and the extent to which the Civil Union Act may be examined in order to give effect to the affirmation of the equal rights of persons in same-sex relationships. The distinction strikes at the core of section 9(2) of the Bill of Rights as argued by Moseneke $\mathrm{J}$ in Van Heerden. ${ }^{40}$ Moseneke $\mathrm{J}$ argues for the development of an effective tool designed to assist and ensure the promotion of the substantive equal rights of all people, including same-sex couples, who have been disadvantaged through unfair discrimination. Such categorisation further undermines the potential of the Civil Union Act itself as an affirmative measure designed to improve the quality of life of persons in same-sex relationships. ${ }^{41}$

In addition, section 3 of the Act endorses the legal separateness of same-sex couples in that it gives same-sex relationships an inferior status by providing that: 'this Act applies to civil partners joined in a civil union' only. 
The section effectively establishes a 'gated community' of same-sex couples confined in a particular 'closet' different from that for heterosexual couples. It leaves (especially same-sex) couples without an option as to whether their relationship will fall under customary law or common law. It confines same-sex couples to engaging in 'so-called marriages,' which are defined as voluntary unions which are solemnised and registered by way of either a marriage or a civil partnership. ${ }^{42}$

It affirms the perception of civil marriages as being superior to customary marriages, which were not incorporated into the national legal framework until the new constitutional dispensation in South Africa. Since the dawn of democracy, South Africa has made inroads into and transformed its marital regime by recognising customary marriages. ${ }^{43}$ The adoption of the Customary $\mathrm{Act}^{44}$ furthered the social and legal evolution of the marital regime in South Africa by giving equal recognition to customary and civil marriages, and also to partners in those marriages. ${ }^{45}$

Although the issue of the perception of the superiority of civil marriages requires further research - it is not comprehensively addressed in this contribution - it may be pointed out that the perception is related to the provision of section 12 of the Customary Act. Section 12 requires the parties to a customary marriage to register it, even though the failure does not affect its validity. The validity of customary marriages in terms of customary law is determined by the negotiations between the bride and the groom's family, payment of ilobola and other procedural requirements. ${ }^{46}$ These procedural requirements were valid determinants of customary marriages. Section 12 introduces the registration of customary marriages and such requirement undermines customary law as a legitimate system of law that is able to regulate

See $s 1$ of the Act.

See Andrews Washington and Lee Law Review 1483.

See (n 37) above.

See the preamble of the Customary Act.

See Maithupfi and Bekker 2009 Obiter 164-174. 
its own affairs and development. It reinforces and supplements the African value system with the Western conceptions of marriage, which are foreign to it, thus undermining the legitimacy of customary marriages. ${ }^{47}$

The Civil Union Act ignored and actually missed an opportunity for addressing some of the complex questions that may be raised, especially within the system of customary law in, relation to the marriage of couples in same-sex relationships. These questions are related to procedural requirements such as the payment of ilobola.

As the customary-law system is uncodified and evolves with changing circumstances, the fact that the Act does not recognise equal access to marriage either in terms of customary or common law puts couples in same-sex relationships at a disadvantage. It increases the vulnerability of couples in same-sex relationships, especially when they are beyond the borders of South Africa, and exposes them to persecution, as evidenced by the recent tabling of the Ugandan Bill prohibiting same-sex relationships. ${ }^{48}$ The Act may also undermine South Africa's obligations under international law as envisaged in the preamble of the Equality Act, which provides that:

South Africa also has international obligations under binding treaties and customary international law in the field of human rights which promote equality and prohibit unfair discrimination.

In essence, this section has closed off an opportunity for parallel development of the existing marital regimes within the context of partners in same-sex relationships. It implies that African traditional values and principles are too conservative in nature. Even if that were to be true ${ }^{49}$ the affirmation of the equal status of marital regimes through either common or customary law may and 235 , where he argues that customary law should be allowed to develop within its own value system.

48 See the report by Olukya Associated Press 8 January 2010.

49 See the report by BBC News 'Homosexuality in Africa' 28 June 2002, in which it was reported that President Robert Mugabe of Zimbabwe described couples in same-sex relationships as being worse than 'dogs or pigs', who, because of their 'unnatural perversion', are not entitled to basic human rights. 
have provided an opportunity for tolerance and accommodation of couples in same-sex relationships within the framework especially of the African value system.

Section 6 of the Act, which is intertwined with section 5 , further provides that:

a marriage officer, other than the one designated in terms of section 5 , may in writing inform the Minister that he or she objects on the grounds of conscience, religion and belief to solemnise a civil union between persons of the same sex, whereupon that marriage officer shall not be compelled to solemnise such civil union.

The equal contest between the right to freedom of sexual orientation and the right to freedom of religion has made the development of the principles of nondiscrimination subject to the social, moral and legal convictions of those authorised to solemnise marriages. It allows the enforcement of equal rights to depend on the willingness of marriage officers to use their discretion in balancing their constitutional rights to religion and the right of same-sex couples to equal benefit of the law. It is equally striking that officers employed to conduct public service in line with the values and principles of public administration $^{50}$ will have to make potentially difficult decisions whether to marry same-sex couples or not. It has actually created a constitutional crossroads ${ }^{51}$ which same-sex couples will not be able to cross in order to solemnise their relationships as marriages. It reinforces the formal conception of the law without actually moving beyond its own limitations. It also minimises the specific-rights perspective which motivated the adoption of the Civil Union Act.

Whether same-sex couples have access to marriage or not depends on the convictions of marriage officers who often do not wish to recognise the difference between same-sex and heterosexual couples, wishing instead to eliminate the consequences of such differentiation. But the issue is whether or not heterosexual and same-sex couples are receiving identical treatment rather

50 See s 195 of the Constitution and the Public Service Act 103 of 1994, which seek to regulate and improve governance in public administration in support of vision and efficiency and increased public participation in governance.

$51 \quad$ See Strasser On Same-sex Marriages 24. 
than whether or not the Civil Union Act, through its effective application and proper interpretation, will be able to eliminate the unequal consequences of such differentiation. For example, by having adopted the Civil Union Act, the government has acknowledged that same-sex couples are identically situated to heterosexual couples in relation to the marital laws of South Africa.

As argued elsewhere, the 'differentiation approach' not only prohibits differential treatment, but also allows for differentiation in appropriate cases to enhance the respect and the promotion of fundamental freedoms for everyone. ${ }^{52}$ The identical treatment of similarly situated individuals (same-sex and heterosexual couples) without an adequate justification of the legitimate purpose of the government runs contrary to the principles of non-discrimination. ${ }^{53}$

In this regard, the failure of the Act to recognise the difference between and identity of same-sex and heterosexual couples undermines the argument by Sachs $\mathrm{J}$ in Fourie, where he argues that:

a democratic, universalistic, caring and aspirationally egalitarian society embraces everyone and accepts people for who they are. To penalise people for being who and what they are is profoundly disrespectful of the human personality and violatory of equality. Equality means equal concern and respect across difference. It does not presuppose the elimination or suppression of difference. Respect for human rights requires the affirmation of self, not the denial of self. Equality therefore does not imply a levelling or homogenisation of behaviour or extolling one form as supreme, and another as inferior, but an acknowledgement and acceptance of difference. At the very least, it affirms that difference should not be the basis for exclusion, marginalisation and stigma. At best, it celebrates the vitality that difference brings to any society. ${ }^{54}$

The identical treatment of different types of couples within the framework of the right to freedom of religion fails to acknowledge the significance of the law in dealing with both the legal and socially constructed roles that seek to compromise the equal worth of the rights of same-sex couples. Such treatment undermines the already developed jurisprudence that has emanated from the 
Constitutional Court on equality, that focusing on the impact of the differentiation on vulnerable groups, including same-sex couples. ${ }^{55}$ The jurisprudence has put an emphasis on the substantive realisation of the right to equality. The purpose of such an emphasis is to establish a future that is founded on the ideals of reconciliation in and reconstruction of our society. ${ }^{56}$ The right to equal benefit of the law cannot be a 'throat-clearing' exercise, as argued by Sachs $\mathrm{J}$ in Mhlungu, ${ }^{57}$ if it has to equally address the intense suffering of the past and the injustice which continues to manifest itself in this new constitutional dispensation.

The contest between the right to freedom of religion and the right to freedom of sexual orientation in the Civil Union Act has made the substantive translation of the right to equality subject to a 'mere choice'. The choice enables the marriage officers to use their discretion, forcing them to draw a distinction between people, which perpetuates the privileges of couples in heterosexual relationships, as argued by Langa CJ in MEC for Education: KwaZulu-Natal $v$ Pillay ${ }^{58}$ that:

[the discretion] enforces mainstream and historically privileged forms ... at the expense of minority and historically excluded [groups]. It thus places a burden on [partners in same-sex relationships] who are unable to express themselves fully ... in an environment that does not completely accept them. ${ }^{59}$

The foundation for the relegation of substantive principles such as the right to equality to such a discretion or a "mere choice" was laid down by the Court in Fourie, where it was held that:

religious institutions would remain undisturbed in their ability to perform marriage ceremonies according to their own tenets, and thus if they wished, to celebrate heterosexual marriages only. ${ }^{60}$ 
The choice forces marriage officers to make difficult decisions by weighing different considerations on what would constitute an allegiance to religious beliefs against the their faith in the equal worth of all people. This contention was affirmed by Sachs $\mathrm{J}$ in Christian Education of South Africa $v$ Minister of Education, ${ }^{61}$ who argues that:

the underlying problem in any open and democratic society based on human dignity, equality and freedom in which conscientious and religious freedom has to be regarded with appropriate seriousness, is how far such democracy can and must go in allowing members of religious communities to define for themselves which laws they will obey and which not. Such a society can cohere only if all its participants accept that certain basic norms and standards are binding. Accordingly, believers cannot claim an automatic right to be exempted by their beliefs from the laws of the land. At the same time, the state should, wherever reasonably possible, seek to avoid putting believers to extremely painful and intensely burdensome choices of either being true to their faith or else respectful of the law. ${ }^{62}$ (own emphasis).

Marriage officers subscribing to certain religious beliefs may marginalise samesex couples seeking marriage because they do not or cannot conform to 'perceived certain acceptable' social norms. ${ }^{63}$ It further leaves uncertainty regarding the genuineness of subscription to religious beliefs and an unwillingness to solemnise same-sex marriages. Although the above falls outside the scope of this contribution, it may require resource-intensive further research.

In essence, the Civil Union Act does not put same-sex couples on an equal footing with heterosexual couples as far as all of the other rights and responsibilities enjoyed by the latter group are concerned. The right of access to marriage has become a prerogative of heterosexual couples. The Civil Union Act relegated this right to a secondary position for same-sex couples, thus systematically institutionalising their stigmatisation. The fact that the 'status' of marriage in the Civil Union Act is not available to same-sex couples is a cause for concern. It defeats any transformative value that the acceptance of same- 
sex marriages may have as far as the concept 'marriage' is concerned, because the Act does not deconstruct the old standing principle that marriage is between a 'man and a woman to the exclusion of others'. ${ }^{64}$

The denial of the equal status of marriage for same-sex couples compromises the potential of using the law as a strategy for social change. As Kakabadse puts it:

law is an ideology of justice that encompasses equal accessibility which must lead to the results that are individually and socially just. ${ }^{65}$

In this regard, the legal separateness of equal rights for same-sex vis-à-vis heterosexual couples has created a 'social, legal and constitutional dilemma' regarding the central role of the law and its impact on the manner in which members of society should relate to one another. The interdependence of law and social justice provides an opportunity for examining the existence of underlying social ills that could be harmful to our society.

Of great concern is the fact that the interaction between the law and society forms the basis for understanding not only the law itself, but also broader issues relating to equality and social justice. Sachs $\mathrm{J}$ in Port Elizabeth Municipality $v$ Various Occupiers ${ }^{66}$ framed the intersection of the law and social justice within the prescripts of the African value system, which embraces concepts such as 'ubuntu'". He argued as follows:

thus, [the law] expressly requires the court to infuse elements of grace and compassion into the formal structures of the law. It is called upon to balance competing interests in a principled way and promote the constitutional vision of a caring society based on good neighbourliness and shared concern. The Constitution confirms that we are not islands unto

See the report by SAPA The Sowetan 28 January 2010, where it is reported that a complaint of hate speech has been laid with the South African Human Rights Commission in Mpumalanga against the Pan Africanist Youth Congress. It is alleged that the Youth Congress had gone to the extent of undermining not only the dignity of same-sex couples but the Constitution itself, as quoted in the newspaper: 'We are saying to hell with the SA Constitution for giving rights to gays and lesbians. Homosexuality is totally immoral and there is no place for gays and lesbians'. 
ourselves. The spirit of ubuntu, part of the deep cultural heritage of the majority of the population, suffuses the whole constitutional order. It combines individual rights with a communitarian philosophy. It is a unifying motif of the Bill of Rights, which is nothing if not a structured, institutionalised and operational declaration in our evolving new society of the need for human interdependence, respect and concern. ${ }^{67}$ (own emphasis)

Therefore, the disparity of equal access to marriage endorses an argument by Faundez that legal reform is a 'fatal attraction', as he contends that:

the adoption of these laws is not always the best of the alternatives available to permeate every facet of the laws because social problems are not always resolved by enacting new rules. It is often the case that new legal rules are not the best solution either because there is no agreement in society as to the content of the rules or because the rules simply do not reach the group that they are meant to reach. ${ }^{68}$

Although the Civil Union Act is important for a number of reasons, the institutionalised limitation of the right to equal access to marriage gives credence to Faundez's argument. The Act does not give sufficient recognition to the status of same-sex couples. Despite the positive features of the Act, its adoption has created a separate status that strengthens the view that same-sex couples do not deserve the same status and respect as heterosexual couples. The positive features of the Act are outweighed by the disadvantages it brings for the recognition of the equal status of all marriages in South Africa. Overall, the factors discussed above, give effect to what Davis refers to as the 'emperor that is still naked', ${ }^{69}$ as they pose difficulties in relation to the implementation of the Civil Union Act.

\section{Conclusion}

Having provided more questions than answers, the Fourie judgment just captured the scenario by laying the foundation for the adoption of the Civil Union Act. This Act serves as the litmus test for the promotion and achievement 
of equality in South Africa. The promotion of human-rights standards and obligations associated with the right to equality remains at the core in consolidating our hard-fought democracy. South Africa's Constitution requires social, legal and constitutional equality, but the fact that civil marriages or unions remain a separate institution for same-sex couples represents a real and powerful inequality. ${ }^{70}$ Having the right to equality on paper means very little if it will not effectively impact on, and change the lives of couples in same-sex relationships. There is a danger that South Africa used the rhetoric of equality just to keep up appearances. 


\section{Bibliography}

Andrews 2007 Washington and Lee Law Review

Andrews $\mathrm{P}$ "Big Love? The recognition of customary marriages in South Africa" 2007 (4) Washington and Lee Law Review 1483

Bonthuys 2008 Sexualities

Bonthuys E "Possibilities foreclosed: the Civil Union Act and lesbian and gay identity in Southern Africa" 2008 (6) Sexualities 726

Davis 2009 Vanderbilt Journal of Transnational Law

Davis $\mathrm{K}$ "The emperor is still naked: why the protocol on the rights of women in Africa leaves women exposed to more discrimination" 2009 Vanderbilt Journal of Transnational Law 949

Faundez 2002 SELA

Faundez S "Law, social change and lawyers in Chile: from the shrillness of the 60 s to the silence of today" 2002 SELA 6.

Gertsmann Same-sex Marriages

Gertsmann E Same-sex Marriages and the Constitution (Cambridge University Press New York 2004)

Jagwanth "Expanding Equality"

Jagwanth $S$ "Expanding Equality" in Murray C and O'Sullivan M (eds) Advancing Women's Rights (Juta Publishers Cape Town 2005) 
Kakabadse 2001 Women in Management Review

Kakabadse K "Inequality discourse: problematic consumption of justice in common legal system" 2001 (3) Women in Management Review 241

Klein and Redman 2009 Connecticut Law Review

Klein B and Redman D "From separate to equal: litigating marriage equality in a civil union state" 2009 Connecticut Law Review 1383-1396 and 1394

Laycock, Picarello and Wilson (eds) Same-sex Marriage

Laycock D, Picarello AR Jr and Wilson RF (eds) Same-sex marriage and religious liberty: emerging conflicts (Beckett Fund for Religious Liberty and Rowman \& Littlefield 2008)

Maithupfi and Bekker 2009 Obiter

Maithupfi IP and Bekker JC "The existence and proof of customary marriages for purposes of Road Accident Fund claims" Obiter 164-174

Mokgoro 2003 Albany Law Review

Mokgoro $Y$ "Constitutional claims for gender equality in South Africa: a judicial response" 2003 Albany Law Review 1

Ntlama 2009 Malawi Law Journal

Ntlama N "Masiya: gender equality and the role of the common law" 2009 (1) Malawi Law Journal 117

Robinson and Swanepoel 2004 PER

Robinson JA and Swanepoel J "Same-sex marriages in South Africa: The road ahead" 2004 (1) Potchefstroom Electronic Law Journal 87-135 
Strasser On same-sex Marriages

Strasser M On same-sex marriages, civil unions and the rule of law: constitutional interpretation at the crossroads (Praeger Publishers London 2002)

Wintemute Legal Recognition

Wintemute $\mathrm{R}$ Legal recognition of same-sex partnerships: a study of national, European and international law (Hart Publishing Oxford-Portland Oregon 2001)

\section{Register of legislation and policy documents}

Constitution of the Republic of South Africa, 1996

Civil Union Act 17 of 2006

Marriage Act 25 of 1961

Promotion of Equality and the Prevention of Unfair Discrimination Act 4 of 2000

Recognition of Customary Marriages Act 120 of 1998

\section{Register of court cases}

Amod v Multilateral Motor Vehicle Accident Fund 199712 BCLR 1726 (CC)

Azapo v President of the Republic of South Africa1996 8 BCLR 1015 (CC)

Bato Star Fishing (Pty) Ltd $v$ Minister of Environmental Affairs and Tourism 20047 BCLR 687 (CC)

Bhe $v$ Khayelitsha Magistrate 20051 BCLR 1 (CC)

Carmichele v Minister of Safety and Security 200110 BCLR 995 (CC) 
Christian Education of South Africa v Minister of Education 200010 BCLR 1051 (CC)

Harksen v Lane 199711 BCLR 1489 (CC)

MEC for Education: KwaZulu-Natal v Pillay 20082 BCLR 99 (CC)

Minister of Finance v Van Heerden 200411 BCLT 1125 (CC)

Minister of Home Affairs v Fourie 20061 SA 542 (CC)

Moseneke $v$ The Master20012 BCLR 103 (CC)

National Coalition for Gay and Lesbian Equality v Minister of Justice 19981 BCLR 1517 (CC)

Port Elizabeth Municipality v Various Occupiers 20041 BCLR 1268 (CC)

President of the Republic of South Africa v Hugo 19976 BCLR 708 (CC)

S v Makwanyane 19956 BCLR 335 (CC)

S v Mhlungu 19957 BCLR 793 (CC)

\section{List of unpublished sources and newspaper reports}

BBC News: 'Homosexuality in Africa' 28 June 2002

Olukya G 'Ugandan lawmaker refuses to withdraw the bill' Associated Press 8 January 2010

President Thabo Mbeki ANC Today 8 Aug 2002

Reddy V 'The same-sex marriage complex in South Africa: some conceptual, gendered and rights-based interpretations' presentation at a one day workshop entitled: Is same-sex marriage ethical? Unilever Ethics Centre, University of KwaZulu-Natal, Pietermaritzburg

SAPA: 'PAC in trouble over hate speech' The Sowetan 28 January 2010 